\title{
Electrical Overstress
}

National Cancer Institute

\section{Source}

National Cancer Institute. Electrical Overstress. NCI Thesaurus. Code C63218.

Problem associated with electrical activity of the device that exceeded the specified threshold limit of the internal integrated circuitry. 